慶應義塾大学学術情報リポジトリ

Keio Associated Repository of Academic resouces

\begin{tabular}{|c|l|}
\hline Title & $\begin{array}{l}\text { Single column ion exchange separation of the transplutonium elements from uranium targets } \\
\text { bombarded with heavy ions and catcher foils }\end{array}$ \\
\hline Sub Title & \\
\hline Author & $\begin{array}{l}\text { 臼田, 重和(Usuda, Shigekazu) } \\
\text { 篠原, 伸夫(Shinohara, Nobuo) } \\
\text { 吉川, 英樹(Yoshikawa, Hideki) }\end{array}$ \\
\hline Publisher & 共立薬科大学 \\
\hline Publication year & 1988 \\
\hline Jtitle & $\begin{array}{l}\text { 共立薬科大学研究年報 (The annual report of the Kyoritsu College of } \\
\text { Pharmacy). No.33 (1988.),p.175-175 }\end{array}$ \\
\hline JaLC DOI & \\
\hline Abstract & \\
\hline Notes & 抄録 \\
\hline Genre & Technical Report \\
\hline URL & https://koara.lib.keio.ac.jp/xoonips/modules/xoonips/detail.php?koara_id=AN00062898-0000003 \\
3-0175
\end{tabular}

慶應義塾大学学術情報リポジトリ(KOARA)に掲載されているコンテンツの著作権は、それぞれの著作者、学会または出版社/発行者に帰属し、その権利は著作権法によって 保護されています。引用にあたっては、著作権法を遵守してご利用ください。

The copyrights of content available on the KeiO Associated Repository of Academic resources (KOARA) belong to the respective authors, academic societies, or publishers/issuers, and these rights are protected by the Japanese Copyright Act. When quoting the content, please follow the Japanese copyright act. 


\title{
Single Column Ion Exchange Separation of the Transplutonium Elements from Uranium Targets Bombarded with Heavy Ions and Catcher Foils*
}

\author{
Shigekazu UsudA ${ }^{* *}$, Nobuo ShINoHARA**, Hideki YoshIKaWA* \\ 臼田重和**，篠原伸夫**，吉川英樹
}

\begin{abstract}
A simple pressurized ion exchange apparatus has been devised for rapid ion exchange separation of transplutonium elements synthesized by heavy ion bombardment. Cation exchange with mixed media of mineral acids and organic solvents at elevated temperature was used to separate the transplutonium elements from uranium targets and/or catcher foils (aluminium and copper) dissolved in aqua regia. The transplutonium elements were strongly adsorbed on the cation exchange column and separated in a group from rare earths by elution with hydrochloric acid or mutually separated with 2-hydroxy-2-methylpropionate solution. It has been successfully applied to separate and identify ${ }^{250} \mathrm{Fm}$ and ${ }^{246} \mathrm{Cf}$ synthesized by the ${ }^{16} \mathrm{O}+{ }^{238} \mathrm{U}$ reaction.
\end{abstract}

* 本報告は Journal of Radioanalytical and Nuclear Chemistry, Articles, 109 (2) , 353-361 (1987) に 発表.

** 日本原子力研究所 